\title{
E-COMMERCE: THE VIRTUAL BATTLEFIELD
}

\author{
Tracy Litzinger \\ Embry-Riddle Aeronautical University, USA litz@aug.com \\ John A. Wise \\ Embry-Riddle Aeronautical University, USA wise@db.erau.edu
}

It seems reasonable that one would want to use intelligent agents with different ways of behaving to perform different tasks in e-commerce. This paper considers how intelligent agents might behave in e-commerce environments, if their behaviors were modeled after different human "personality characteristics." In particular, an e-commerce agent based on Machiavelli's principals is discussed and compared to one with anti-machiavellian behaviors.

\section{INTRODUCTION}

Over the past decade, we have been witness to a radical change in the pervasiveness of technology. E-commerce success has helped produce a global economic system where almost every major company and country in the world trades commodities via the Internet. Sales through e-commerce are expected to grow to $\$ 1.2$ trillion (US) by 2002 (Cohen, 2000). This business phenomenon never stops; 24 hours a day, seven days a week, information is exchanged and money is bartered. We, as consumer, must form opinions and make judgments while marketers can use the Web to learn about our preferences and interests. These powerful operations begin the rampart and continuance of conflict in our virtual free market. To participate in this conflict, you must become a soldier; perhaps, your own general. You must gather information, make a strategic assessment, and fight the battle. The vitality of e-commerce on the Web has created a rush to deliver better assistants to online customers. It is not so unrealistic to think of these shopping agents as virtual soldiers defending our position, hunting out beneficial market developments, acquiring new positions, and winning the business war.

\section{AGENTS}

You give a "bot" (i.e., robot) directions and it will bring back answers. The term "bot" has become interchangeable with "agent" to show that the software can be sent out on a mission, usually to find information and report back. Agents have a variety of definitions. For instance, Sycara (Brent \& Thompson, 1998) defines an 
agent as "a computer software system whose main characteristics are situatedness, autonomy, adaptivity, and sociability." Situatedness means that the agent must perceive at least some aspects of its environment and change its environment in some manner. Autonomy requires that the agent have control over its own actions and be able to act on its environment without human intervention. Adaptivity requires that the agent be able to respond flexibly to changes in its environment, to learn from experience, and to take initiative by performing goal-directed tasks when appropriate. The more intelligent an agent the more adaptive it would be. Sociability requires an agent to be capable of interacting with humans or other agents. We should be able to communicate with them at an abstract level in which they share our goals rather than merely processing our commands. We should be able to delegate to them the task of figuring out how to achieve those goals, come back to us and show us what went wrong or what else is needed to fulfill them.

Kater, chief technology officer for Artificial Life, Inc., believes that intelligent agents will evolve through three stages: 1) personal assistants (simple independent entities), 2) specialized agents (capable of communicating with each other), and eventually 3) autonomous agents that act on the customers behalf. "If Kater's predictions apply to agent evolution in general, then you can expect to see a growing community of agents that become more and more interconnected while taking ever greater degrees of autonomy," suggests Barker (1999). In a few years, agents may be collaborating and cooperating across the web, delivering a wide variety of services and products (Barker, 1999). Researchers at MIT and IBM are preparing for a world in which every transaction will become a complex trade deal between a pricing bot acting for the site and a shopping bot acting for the customer. Kephart, manager of the agents and e-merchant phenomena group at IBM, explains that price bots do not understand that undercutting competitors is not always smart. In tests, the sell bots have given the store away in a competitive frenzy. He notes, "They're pretty dumb. We have to give them a sense of anticipation" (Taylor, 1999). "Dumb," "a sense of anticipation," are these words depictions of human traits?

Yes, the line between social interaction among humans and human to computer interaction is beginning to blur. Our own social interaction is complex and encompasses a variety of interactions, from a one-way transfer of information, to bargaining and negotiation, to an exchange of emotions. Today, intelligent agents in the form of engaging interactive characters offer advantages over traditional computer interfaces. They permit people to interact using natural forms of conversation and gestures, they add interest and warmth to the online experience, and they build relationships of trust with users. Communication Technologies Research Group ${ }^{\mathrm{TM}}$ found that people tend to treat computers as though they were humans. Some of the social interaction models for computer agents draw on examples of our social life including: a hierarchy in which some agents have more authority than others, a community of experts in which each agent specializes in different tasks, a market in which agents compete for tasks and resources, and a scientific community in which agents propose solutions and communicate with each other to test or refine solutions. Currently, researchers are attempting to assign intelligent agents with distinct personalities and social roles (Brent \& Thompson, 1999).

Just as one would select certain employees over others to perform various tasks because of their personality and/or general business approach, it seems equally reasonable that one would want to use different intelligent agents to perform 
different tasks in the e-commerce world. Churchman (1971) made a compelling argument that one of the basic issues in the design of a computer-based systems that perform historically human tasks is to determine what set of human attributes should the computer-based system have. The classic discussion of this question is best described in his book, The Design of Inquiring Systems (Churchman, 1971). In this classic work, Churchman examined how computer-based inquiring systems would behave if they were designed based on one of the epistemologies of five major western philosophers (i.e., Leibnitz, Locke, Kant, Hegel, or Singer). He demonstrated that not only do systems that are based on different epistemologies generate different types of answers to the same inquiry, but they generate different numbers to answers!

What if one such personality considered for computer transfer is based on the "ends justifies the means" philosophy of Machiavelli? Instead of using classic epistemologies or well established personality theories, this paper will examine how Machiavellian principles could impact the design of an intelligent agent and how the Machiavellian agent would behave compared to an agent developed using a stereotypical scientist/engineer model of behavior. The later is probably a reasonable model for a large percentage of current agents. E-engineering design tends to be based on what we already know or assume to be true.

\section{MACHIAVELLI}

The name Niccolo di Bernado Machiavelli evokes the very essence of politics and conflict. He was a historian, statesmen, and political philosopher, whose influential writings have turned his name into a synonym for cunning and deceit. For instance, to label someone "machiavellian" is to accuse him of manipulating others in an opportunistic and deceptive way (Curry, 1999). "Machiavellianism" has come to represent corruption and totalitarian rule, where men may indulge in whatever acts no matter how dishonorable (Brewer, 1894). At every opportunity Machiavelli watched great leaders to study their political tactics. His handbook, The Prince (1532), is packed with advice on how to get power and keep it. The main theme is that princes should retain absolute control of their territories, and they should use any means of expediency to accomplish this end. His descriptions continue to be studied today for its methods of leadership and administration.

Machiavelli wrote about people management and warfare, and concluded that success and failure of states stems directly from the qualities of its leaders and their soldiers. So, there is value in revisiting the basic principles identified by Machiavelli and determining whether or not these qualities would be applicable to the evolution of electronic agents.

Jay (1968) describes a hierarchy in today's management structure that is very similar to Machiavelli's concepts of management, leadership and organization. "The new science of management is in fact only a continuation of the old art of government, and when you study management theory side by side with political history, you realize you are only studying two very similar branches of the same subject," explains Jay. For example, it was a monumental feat of management that the Roman Empire grew so large and survived so long. Management had no control over its agents since there were few roads, no spy planes, and no telephones. They could not attempt to give direction by picking up the telephone or tracking 
movement overhead. When a Roman agent was delegated or an army was sent forth, Rome watched him disappear in his chariot or march over the hill. Therefore, Rome had to have complete confidence in the weltanschauung of that agent. They had to believe that the agent would behave exactly as they expected, even in unpredictable situations (Jay, 1968, p. 63).

\section{THE MACHIAVELLIAN AGENT}

Who is the Machiavellian agent? What are their trusted social roles? Machiavelli characterizes his agent hierarchy as: creative leaders, staffers and subordinates. The essence of the creative leader is the contemplated commander, the thinker, as well as a man of action (Jay, 1968). According to Machiavelli, leaders must know how to act like beasts; they must be able to imitate the lion and the fox. One needs to be the fox to recognize traps and a lion to frighten away the wolves. Leaders that rely solely on the strength of a lion do not understand the modus operandi (Ames, 1994). Machiavelli expected rulers to commit acts of cruelty as necessary to secure one's position. He believed that rulers may be excused for performing such acts of violence and deception and are not bound by traditional ethical norms. Furthermore, these acts are morally justified. Machiavelli said that leaders must be accomplished liars and be able to make themselves look good even when they are doing evil (Curry, 1999).

Machiavelli also suggested that strong leaders will often have a number of staffers, which he called barons and courtiers, to sweep up after them and to make up for the leader's shortcomings. A baron is usually far away keeping invaders from the borders, whereas, a courtier is close by actually shadowing the "boss" and forming some sort of order out of his ideas so that the lesser people can carry them out efficiently (Jay, 1968).

Machiavelli believed subordinates should consolidate an army. These soldiers should have the greatness of their country (not their personal fate) as their highest goal. They should be willing to sacrifice everything for their political beliefs even to die for them. Only these qualities could make the soldiers for an unstoppable army. Machiavelli remarked that good discipline constitutes the foundation of a good army. "Good order makes men bold and confusion cowards. Few men are brave by nature, but good order and experience make many so. Good order and discipline in an army are more to be depended upon than courage alone," states Machiavelli (Earle, 1971). He adds, unless their leader is thought to be harsh, armies are not unified or prepared for military action (Salmon, 1995).

\section{PRODUCING A MACHIAVELLIAN AGENT}

How would an e-engineer design the personalities and social roles that resemble patterns of Machiavellian behavior? It is an attempt to produce intelligent behavior on a computer that is limited, first and foremost, by the amount of knowledge we hold about people. These expert systems with mechanized domains of knowledge will require thousands of rules. We would expect the stereotypical expert system to possess: 1) an efficient system of information-receiving 2) an ample information- 
store 3) an efficient system that can modify its storage, its storage-system or even its methods of processing as a result of its making use of the information it has received 4) a means of communicating its decisions to the outside world, and that it will at intervals find it expedient to communicate them in some form (Yazdani \& Narayanan, 1984).

One could also adopt the lessons of IBM's Deep Blue. Its strengths are in the machine. It operates like a turbocharged expert system drawing on vast resources of stored information and then, in a timely manner, calculates the most appropriate response to an opponent's move. It never tires, forgets, or gets distracted. Deep Blue does not incorporate psychological tactics, per se. It can neither intimidate nor be intimidated, and experiences no joy from winning or sadness from losing.

Or, consider employing the U.S. Army's doctrinal foundations on the principles of war. There are nine principles that provide general guidance for the conduct of war at the strategic, operational, and tactical levels. They are: 1) objective, 2) offensive, 3) mass, 4) economy of force, 5) maneuver, 6) unity of command, 7) security, 8) surprise, and 9) simplicity (HQ, U.S. Army, 1993).

Mitroff's model, which is based on Churchman's concept, applies to a number of basic business problems that could also be applied to the creation of this intelligent agent. He explains that different forms of inquiry are best suited for different types of business problems. For example, solving structured and unstructured problems require different methods (Mitroff \& Linstone, 1993). Likewise, the identification of the real problem in a complex environment is influenced by the form of inquiry used (1997). And, the best way(s) of getting around roadblocks can either be illuminated or completely occluded by the method of inquiry utilized (Mitroff \& Linstone, 1993).

According to Machiavelli, there was only one answer to plug into the equation of right and wrong; the success or failure of the action, therefore, this task should be simple. Next, design an artificial system that refuses to communicate its results, or communicates them only at unpredictable intervals, or whose results we are powerless to modify and voila, we begin to see a deceptive and paranoid force developing. This is a tool that makes it possible for an evil agent to continue his evil ways without the citizens or the users knowing. Also, devise efficient methods of deceiving the enemy and employing tricks-like spreading false rumors. Machiavelli's prince never used emotion in his decision-making or sought advice from others. The agent will also rely on a well-developed ability of foresight and evaluating history in terms of consequences. He will know how to make distinctions, how to consider alternative courses of action, how to make approximations of operative motives, and utilize this guess-work as to the tactics of his opponents. An offensive spirit will be inherent in the conduct of the agent and it will direct every action toward achieving a defined objective. Synchronizing and judiciously employing the "soldiers" will even enable smaller forces to achieve desired results. Effectively maneuvering and striking when the enemy is unprepared can gain positional advantage. Finally, they will need to know how to apply general information about human nature to the particular circumstances that they face before taking any action. 


\section{SENDING THE MACHIAVELLIAN AGENT "INTO BATTLE"}

Who has time to comparison shop on-line? Machiavel does. Let's send him on a mission to scour net stores and search out deals. Ready...I fire-up my wireless, teleputer. Set... "I need a vehicle. Something in the \$30,000 range," I say. "Make it red." Go...I sit back and relax in my La-z-Boy® recliner confident that Machiavel is fast and smart and knows exactly what I like.

The cut-throat business of car dealing is a perfect site to set Machiavel free. He immediately peruses the web looking for specific URLs, in and out of corners, collaborating with staffers and ally agents, checking links and positions, directing subordinate agents to search for one of those pricier SUVs, with a V-8 engine, allied wheels, air-conditioning, CD player, automatic driver-side seats, a sunroof, oh, and red. Aha, a potential seller. Machiavel and his army pummel the site with fraudulent hits requesting information and bids on that very same SUV. He sends his barons to block the site's access. This tactic usually tricks the seller into thinking business is up and competition is more assured. Machiavel makes an offer, " $\$ 30,000$ for that SUV or else!" The dealer stands firm. The list price is $\$ 35,995$. Machiavel thinks fast. "My client will pay cash," he announces. The price is now $\$ 34,000$. Machiavel mentions the client's VW Bug that will be used as a trade-in. The price is now down to $\$ 32,000$. Machiavel, now irritated with the seller's incremental provocations, decides to take another course of action. He leaves the site. No, not to check in with the client, but to make the dealer believe he actually obtained a quote for the same SUV, only in green, from another dealer one site over. The quote -- $\$ 29,200$. The dealer overwhelmed by competition and the enormous volume of sudden requests for SUVs, closes with a price of $\$ 30,000$. Mission accomplished. Machiavel giggles to himself, amused by his victory. He neglected to tell the dealer, the trade-in could often be found on the crash derby circuit, one of his client's favorite past-times. Machiavel finally reports his status. Acting surprised I say, "Machiavel, you took longer than I thought!" "Yeah, yeah," Machiavel quips. "By the way, I have withdrawn $\$ 30,000$ from your checking account."

\section{THE “ANTI-MACHIAVELLIAN" AGENT}

Those rulers that have achieved great things in our own times have all been considered harsh; all others have failed. Machiavelli believed a ruler, especially a new ruler, cannot always act in ways that are considered good. In order to maintain his power, he is often forced to act treacherously, ruthlessly, or inhumane (Salmon, 1995). However, if the system's intelligence is made passive, goalless, and unable to draw conclusions from its experiences the agent would lead a completely virtuous life. These traditional virtues such as: mercy, generosity, honesty, and loyalty, truly "anti-machiavellian" traits, would dominate. One would expect to see an agent that is obedient, soft, and lacks a fighting spirit. According to Machiavelli, the practice of virtue will not result in success. The leader, Cesare Borgia, whom Machiavelli often cites as the model of virtue, nevertheless, failed (Salmon, 1995). It would be unprecedented to create a simulation for each of these agents to actually behave in 
respect to their assigned attributes in order to determine which is more successful. Until then, let's explore the same scenario described earlier for our "antimachiavellian" agent assuming the polite western style.

\section{THE “ANTI-MACHIAVELLIAN" AGENT'S BATTLE}

On her daily stroll through the web with a list in hand of her owner's latest desires, Princessa stumbles upon the URL for Buy from the Nice Guy Automobiles Direct. "Oh, just who I've been looking for," she exclaims. Princessa knocks at the access gate and announces herself. "Hello! I've come to purchase an automobile. A big, green SUV, with a V-8 engine, allied wheels, air-conditioning, CD player, automatic driver-side seats, and a sunroof. Hello, anyone here?" The dealer bounds onto the site, "Hi, I am Mr. Nice Guy. You won't find any tricks or gimmics at this site. No siree, bob! Mam, I was put on this earth to sell you a vehicle today!" Princessa kindly repeats her request. The dealer immediately finds that exact SUV and states the asking price -- $\$ 35,995$. Quickly reviewing her owner's finances she explains the price is just too high. "We just can't afford that beautiful piece of steel," she cries. The dealer reacts by saying, "Oh, did I say $\$ 35,995$ ? I meant $\$ 34,000$ !" Princessa pulls the dealer aside and whispers, "My owner works hard for his money and really wants this car, but only has $\$ 30,000$ cash in his bank account to pay for it." Princessa also mentions the classic VW Bug that can be used as a trade-in. "My owner will hate to part with the old, beat-up thing. It is one of his hobbies, you see." The price is now down to $\$ 32,000$. Princessa reports the dealer's cost including the bad news that the Bug must be used as a trade-in. " $\$ 30,000$ is all I have, Princessa. I know you can do it! Go get "em," I cheer. Princessa apologizes to the dealer for making him wait while she reported in with the boss. "It seems we are just going to have to move on to the next site. $\$ 32,000$ is still too high. Thank you for your time," she says sadly. The dealer, hating to lose another customer to the next site over, You've Got the Money, We've Got the Cars, reluctantly cuts the price for the green SUV to $\$ 30,000$. Grateful for the dealer's kindness, Princessa recalls her owner really wanted red. The dealer quibbles, "The asking price is $\$ 35,995$."

\section{CONCLUSION}

"...there is nothing more difficult to carry out, more doubtful of success, nor more dangerous to handle than to initiate a new order of things...the reformer has enemies in all those who profit by the old order, and only lukewarm defenders among those who would profit by the new order"

Machiavelli, 1532/1985

This statement, likely Machiavelli's best known quote, helps to understand the challenges software designers will face as we advance onto the virtual battlefield. All of Machiavelli's methods, while often cruel and drastic, work in today's political and business worlds. Conquering countries (or corporations) is not for the weak hearted. It is a dirty business. And yes, our computerized open markets have 
become a new battlefield, "virtual soldiers" have been set in place, and we are the generals in this conflict doing battle, barking out orders, and taking no prisoners.

\section{REFERENCES}

Ames, C. Machiavelli. 1994. Available: http://www.wwu.edu/ n9610899/. November 30, 1999.

Barker, D. Agents Working Together. PCAI Magazine. Article No. 11. (1999). Available: http://www.botspot.com/pcai/articlel1.htm. December 6, 1999.

Brent, E. \& Thompson, G.A. Sociology: Modeling Social Interaction With Autonomous Agents. Social Science Computer Review 1999; 17(3): 313-22.

Brewer, E.C. The Dictionary of Phrase and Fable. 1894. Available: http://www.bibliomania.com/Reference/PhraseAnd Fable/data/787.html. September 8, 1999.

Churchman, C.W. The Design of Inquiring Systems. Basic Books: New York, 1971.

Cohan, P. A Conversation with Peter S. Cohan. Available: http://www.amanet.org/books/catalog/00544ab.htm. May 19, 2000.

Curry, A. Political Morality? The Washington Post. January 13, 1999: H-1. Available: http://elections98.washingtonpost.com/wp-srv/national/horizon/jan99/moralilty.htm. November 15, 1999.

Earle, E.M. Makers of Modern Strategy_Princeton University Press: Princeton, NJ, 1971.

Headquarters Department of the Army. FM 100-5 Operations. Washington, D.C, June 14, 1993.

Jay, A. Management and Machiavelli. Holt, Rinehart, and Winston: New York, 1968.

Machiavelli, N. The Prince. (H.C. Mansfield, Trans.). The University of Chicago Press: Chicago, 1985. (Original work published 1532).

Mitroff, I.I. Smart Thinking for Crazy Times. Berrett-Koehler: San Francisco, 1997.

Mitroff, I.I. \& Linstone, H.A. The Unbound Mind. Oxford: New York, 1993.

Salmon, M. H. Landmarks in Critical Thinking Series: Machiavelli's The Prince. 1995. Available: http://www.shss.montclair.edu/inguiry/fall95/slamon.html. September 8, 1999.

Taylor, C. Bot Till You Drop. Time (October 11, 1999): 52-3.

Yazdani, M. \& Narayanan, A. Artificial Intelligence: Human Effects. Ellis Horwood Limited: West Sussex, England, 1984. 